\title{
Distribution, abundance and habitat of Palearctic migrants in Lesotho (Maloti/Drakensberg region)
}

\author{
Utbredning, antal och biotopval hos palearktiska flyttfåglar $i$ Lesotho \\ (Maloti-/Drakensbergsregionen)
}

GRZEGORZ KOPIJ

\begin{abstract}
In total 33 Palearctic migrant species have been recorded in Lesotho so far, but more than half of them are uncommon. The most common species include Ciconia ciconia $(1.6 \mathrm{birds} / 10 \mathrm{~km}$ in river valleys and $5.1 \mathrm{birds} / 10 \mathrm{~km}$ outside river valleys), Falco naumanni, Falco amurensis, Actitis hypoleucos (2.1 birds/10 km in large highland rivers and 1.9 birds in Senque River in the lowlands), Phylloscopus trochilus and Muscicapa striata. Data on their densities along water courses and in open grasslands and farmlands in Lesotho are provided. The number of wintering Falco naumanni was estimated at 2500-2800

at eight roosts and that of wintering Falco amurensis at $850-900$ at eigth roosts. The earliest arrival and the latest departure dates are given for most species. In general, the wintering Palearctic bird fauna is poor and the species occur in low densities.

Grzegorz Kopij, Department of Wildlife Management \& Research, University of Namibia, Katima Mulilo Campus, Private Bag 1096, Wenela Rd., Katima Mulilo, Namibia; e-mail: gkopij@unam.na
\end{abstract}

Received 27 March 2013, Accepted 11 September 2013, Editor S. Svensson

\section{Introduction}

Africa is a wintering ground for more than four billion birds from about 200 Palearctic species (Moreau 1972). Even in the most southern regions, such as the Western Cape or Lesotho, several dozens of Palearctic species are recorded every year. There are several gradients in the diversity of migrant species in Africa south of Sahara (Alerstam 1990, map on p. 184). One of the most evident gradients is the decline of the number of Paleactic species from north to south in southern Africa. Another well-known gradient is the decline of species diversity from lower to higher elevations. Both these gradients are relevant in Lesotho that is a high altitude country and one of the most southern regions in Africa.

Compared with the knowledge about species diversity, much less is known about densities of individual species and their affiliation to different habitats and other environmental conditions (Salewski \& Jones 2006). In this paper, I present data on the diversity and phenology, and most importantly, new information about the relative density of Palearctic migrants, based on seven years of field surveys in different habitats and elevation zones in large parts of Lesotho.

\section{Study area and methods}

Lesotho is an enclave within the Republic of South Africa, with a surface area of $30300 \mathrm{~km}^{2}$. The habitat is basically treeless grassland but with a dense river drainage system. For Palearctic species associated with forest the country is therefore rather unsuitable as a wintering habitat. Four zones are recognized in Lesotho: highlands, foothills, lowlands and Senque Valley. The highlands, or Maloti, lie in the altitude between 2200 and $3500 \mathrm{~m}$ above sea level $\left(17887 \mathrm{~km}^{2}\right)$. The highlands are regarded as an endemic region, a so called 'hot-spot'(Cowling \& Hilton-Taylor 1994, Ambrose et al. 2000), and as such should attract the attention of ecologists and conservationists. Lowlands are regarded as the land below $1700 \mathrm{~m}$ a.s.l., while foothills are between 1700 and $2200 \mathrm{~m}$ a.s.l. Lowlands $\left(6051 \mathrm{~km}^{2}\right)$ form a strip of land lying along its northeast-southwest border and extending eastward to the Cave Sandstone Foothills. The foothills $\left(2964 \mathrm{~km}^{2}\right)$ form a narrow band bordering the highlands to the east and lowlands to the west, constituting therefore an intermediate region between the highlands and the lowlands. The Senque Valley Zone is below 1800 $\mathrm{m}$ a.s.l. and occupies $3398 \mathrm{~km}^{2}$ (Ambrose et al. 2000). The natural vegetation is Highveld Grass- 


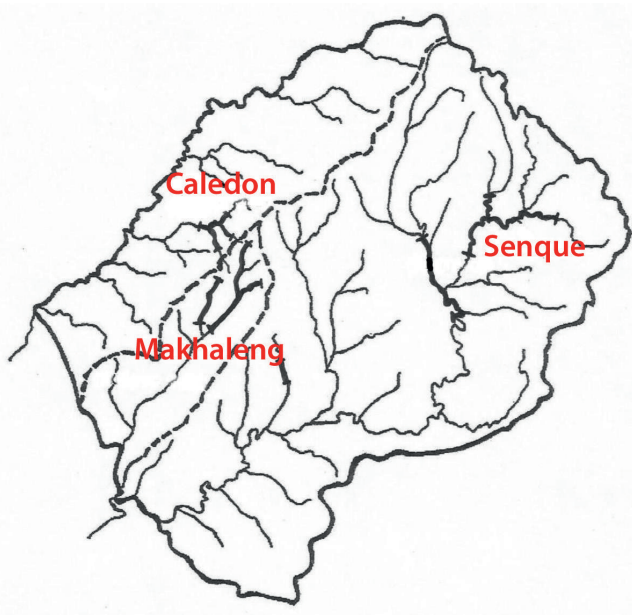

Figure 1. Map of Lesotho showing the river stretches (indicated with thick lines) which were surveyed.

Karta över Lesotho med de flodsträckor som undersökts markerade med tjocka linjer.

land in the lowlands and Afromontane Grassland in the foothills and highlands (Acocks 1988). The population of Lesotho in 2000 was estimated at two million people, lowlands are heavily populated, with more than three fourth of the total, while the population is sparse in highlands.

During the years 1996-2002, I examined the diversity of wintering Palearctic species, their abundance, habitat use and phenology. The most important part of this work was that I made a large number of quantitative surveys in different habitats and at different elevations widely distributed in the country. I used a line transect method without any distance estimates or distance belts, that is I walked slowly along the selected transect and counted the birds irrespective of the distance. Each transect was surveyed once during the austral summer, i.e. from October to March. Transects were fixed in all distinguished ecozones, along selected river courses and along roads and paths in open areas with a mixture of grasslands, arable fields and human settlements. In total, 42 transects (total length: 241 $\mathrm{km}$ ) were walked in river valleys and 89 transects (total length: $506 \mathrm{~km}$ ) outside river valleys (Table 1 and 2).

\section{Results}

\section{The line transects}

During the years 1996-2002, eight Palearctic species were recorded on transects (total length 747 $\mathrm{km}$ ): White Stork, Steppe Buzzard, Common Sandpiper, Wood Sandpiper, Marsh Sandpiper, Common Swift, Willow Warbler, Spotted Flycatcher.

The White Stork was the most abundant species both within and outside river valleys. It was about three times more numerous outside than within the river valleys ( 5.1 versus 1.6 birds per $10 \mathrm{~km}$ ). The low value for river valleys was mainly due to few records along the foothill and the lowland rivers. Although not evident from my line transects it is generally assumed that the White Stork prefers the highlands (mountain grasslands utilized as pastures

Table 1. Wintering roosts of the Lesser Kestrels and Amur Falcons in Lesotho during 1996-2002.

Sovplatser för rödfalk och amurfalk under övervintringen i Lesotho 1996-2002.

\begin{tabular}{|c|c|c|c|c|c|}
\hline No. & Locality & Year & $\begin{array}{r}\text { Lesser } \\
\text { Kestrel }\end{array}$ & $\begin{array}{l}\text { Amur } \\
\text { Falcon }\end{array}$ & Source \\
\hline \multirow[t]{3}{*}{1} & Maseru & 1981 & c. 200 & 1 & Bonde 1993 \\
\hline & & 1991 & $200-300$ & - & A. Abell in Bonde 1993 \\
\hline & & 1998 & c. 1000 & 'a number' & Kopij 2000 \\
\hline \multirow[t]{4}{*}{2} & Roma & 1982 & $300-500$ & - & $\begin{array}{l}\text { Ambrose \& Maphisa } \\
1999\end{array}$ \\
\hline & & 1998 & 522 & 322 & Kopij 2012 \\
\hline & & 2001 & $<200$ & 926 & Kopij 2012 \\
\hline & & 2002 & - & $>282$ & Kopij 2012 \\
\hline 3 & Masitise & 27.02 .2001 & - & 3 & G. Kopij \\
\hline 4 & Between Mohale's Hoek & & & & \\
\hline 5 & $\begin{array}{l}\text { and Mafeteng } \\
\text { Oacha's Nek }\end{array}$ & 27.02.2001 & several & - & G. Kopij \\
\hline 6 & Villa Maria near Quthing & 27.02 .2001 & - & 8 & G. Kopij \\
\hline 7 & Thaba Tseka & 04.03 .2001 & - & 1 & G. Kopij \\
\hline 8 & Mokhotlong & 21.12 .2001 & - & 14 & G. Kopij \\
\hline
\end{tabular}


Table 2. Numbers of Palearctic migrants in river valleys in Lesotho (October-March).

Cc-Ciconia ciconia, Ah-Actitis hypoleucos, Tg-Tringa glareola, Ts-Tringa stagnatilis, Pt-Phylloscopus trochilus.

Antal palearktiska flyttfåglar i floddalar i Lesotho (oktober-mars). Cd-vit stork, Ah-drillsnäppa, Tg-grönbena, $T_{S}$-dammsnäppa, Pt-lövsångare.

\begin{tabular}{|c|c|c|c|c|c|c|c|c|c|}
\hline & \multirow[t]{2}{*}{ Years } & \multirow[t]{2}{*}{ Transects } & \multirow[t]{2}{*}{$\mathrm{Km}$} & \multirow[t]{2}{*}{ Hours } & \multicolumn{5}{|c|}{ Number of birds } \\
\hline & & & & & $\mathrm{Cc}$ & $\mathrm{Ah}$ & $\mathrm{Tg}$ & Ts & $\mathrm{Pt}$ \\
\hline $\begin{array}{l}\text { HIGHLANDS } \\
\text { upper Senque }\end{array}$ & 2001-02 & 13 & 94 & 40 & 7 & 14 & - & - & 4 \\
\hline Malibamatso & 2001-02 & 6 & 35 & 14 & 9 & 2 & - & - & 3 \\
\hline Maletsunyane & 1996-01 & 6 & 26 & 14 & 17 & 3 & 5 & - & - \\
\hline FOOTHILLS & & & & & & & & & \\
\hline Makhaleng & 1998-00 & 6 & 40 & 27 & - & - & - & 2 & - \\
\hline SENQUE VALLEY & & & & & & & & & \\
\hline Senque & 1997 & 26 & 14 & 5 & - & - & - & 1 & \\
\hline LOWLANDS & & & & & & & & & \\
\hline Phutiatsana & 2001 & 13 & 7 & - & - & - & 2 & - & \\
\hline Liphiring & 2002 & 10 & 5 & - & - & - & - & - & \\
\hline Mahlaka-oa-tuka & 2002 & 7 & 4 & - & - & - & - & - & \\
\hline TOTAL & 1996-02 & 42 & 241 & 125 & 38 & 19 & 5 & 4 & 8 \\
\hline
\end{tabular}

for cattle and sheep) and I have observed at least five hundred at other occasions than during the transect work.

The only Paleactic raptor that was seen during the transect work was Steppe Buzzard, and all re- cords were made in the lowlands and Senque Valley away from the rivers. The Steppe Buzzard was encountered on four occasions only; all records were made outside river valleys in the lowlands and Sunque Valley (Table 3).

Table 3. Numbers of Palearctic migrants outside river valleys in Lesotho (October-March).

$\mathrm{Cc}-$ Ciconia ciconia, $\mathrm{Bv}-$ Buteo vulpinus, $\mathrm{Pt}-$ Phylloscopus trochilus, Ms-Muscicapa striata.

Antal palearktiska flyttfåglar utanför floddalar i Lesotho (oktober-mars). Cc-vit stork, Bv-stäppvråk, Pt-lövsångare, $M s-$-grå flugsnappare.

\begin{tabular}{|c|c|c|c|c|c|c|c|c|}
\hline & \multirow[t]{2}{*}{ Years } & \multirow[t]{2}{*}{ Transects } & \multirow[t]{2}{*}{$\mathrm{Km}$} & \multirow[t]{2}{*}{ Hours } & \multicolumn{4}{|c|}{ Number of birds } \\
\hline & & & & & $\mathrm{Cc}$ & $\mathrm{Bv}$ & $\mathrm{Pt}$ & $\mathrm{Ms}$ \\
\hline HIGHLANDS & & (39) & & & (193) & - & (8) & - \\
\hline Farmlands & 1996-00 & 23 & 140 & 78 & 23 & - & 1 & - \\
\hline Mosaic of habitats & $2000-01$ & 10 & 50 & 28 & 150 & - & 3 & - \\
\hline Rural areas & 1996-02 & 6 & 35 & 19 & 20 & - & 4 & - \\
\hline$\overline{\text { FOOTHILLS }}$ & & (24) & & & (7) & - & (1) & - \\
\hline Farmlands & 1997-01 & 7 & 20 & 11 & - & - & - & - \\
\hline Mosaic of habitats & 1999-01 & 7 & 36 & 18 & 7 & - & - & - \\
\hline Rural areas & 1999-01 & 3 & 5 & 3 & - & - & 1 & - \\
\hline Sandstone cliffs & 1999-01 & 7 & 70 & 37 & - & - & - & - \\
\hline SENQUE VALLEY & & (10) & & & (5) & (1) & - & (1) \\
\hline Farmlands & 1997-01 & 3 & 14 & 7 & - & - & - & - \\
\hline Mosaic of habitats & 1997 & 4 & 26 & 14 & 5 & 1 & - & - \\
\hline Rural areas & 2001 & 3 & 5 & 3 & - & - & - & 1 \\
\hline LOWLANDS & & (16) & & & (3) & (3) & $(18)$ & (5) \\
\hline Farmlands & $2000-01$ & 10 & 40 & 20 & & 2 & 1 & - \\
\hline Mosaic of habitats & $2001-02$ & - & 45 & 23 & 3 & 1 & 3 & - \\
\hline Rural areas & 1996-01 & 6 & 20 & 10 & - & - & c15 & 5 \\
\hline TOTAL & & 89 & 506 & 272 & 208 & 4 & 27 & 6 \\
\hline
\end{tabular}


The Common Swift is common throughout Lesotho, mainly in foothills along the sandstone cliffs, and in some larger river canyons, like Senque, Senquenyane and Malibamatso, in the highlands. No attempt was, however, undertaken to quantify numbers of Common Swift, as they are very similar to the African Black Swifts Apus barbatus.

In the highlands, the next most numerous species was the Common Sandpiper. It was restricted to larger rivers, where 2.1 birds per $10 \mathrm{~km}$ were recorded. The records were concentrated in the austral mid-summer. Allan (1999) recorded even lower density of wintering Sandpipers on Malibamatsu $(27 \mathrm{~km})$ on 3 March 1991 (0.4 birds/10 $\mathrm{km})$ and slightly higher density (2.6 birds $/ 10 \mathrm{~km})$ on the same river $(15.5 \mathrm{~km})$ on 11 February 1996. It seems to be equally uncommon in the lower Senque, where a density of 1.9 birds $/ 10 \mathrm{~km}$ has been recorded (Table 2). In the lowland rivers, it has not been recorded at all.

The wintering sandpipers are sometimes accompanied in the river valley habitat by Tringa-species, which are, however, far less common. Only three species were recorded to date: Marsh Sandpiper, Greenshank (one individual) and Wood Sandpiper.

The Willow Warbler belongs to the common Palearctic species in Lesotho. In the highlands, it was associated mainly with indigenous Salix suberecta growing along some water courses and with the alien $S$. babylonica willows growing on the banks of some larger rivers (e.g. Senque, Senquenyane and Malibamatso). In the lowlands it was associated both with willows and the Australian Acacia dealbata bushes, usually close to dams or water courses that were the most often utilized habitats. The Willow Warbler is an elusive species that does not sing during October through February, so numbers are probably underestimated. In March, when its song activity becomes high (Kopij 2009), it proved to be common where counts were conducted. For example, in the rural setting of the Roma campus ( 82 ha) a density of 11-19.5 singing males per 100 ha was recorded (Kopij 2009). Most Willow Warblers wintering in Lesotho belong to the $P$. $t$. acredula subspecies, widely spread in northern Europe and Siberia (Ambrose \& Maphisa 1999, Kopij 2009).

The Spotted Flycatcher was found to be an uncommon migrant to Lesotho. It was recorded only in rural habitats, only in a few villages in the lowlands and one in Senque Valley . Even in intensively investigated areas, such as Roma, Morija and Maseru, which are abundant in suitable foraging habitats, only single birds were recorded (Kopij
2000, 2001a, 2006a). No indigenous flycatchers occur in such habitats (Kopij 2006b).

It is interesting to note that the Palearctic swallows are uncommon, and no record was made during my line transects. No large roosting flocks, known from the neighbouring Free State (Kopij 2000b, Nuttall 2003), have ever been recorded in Lesotho. No Sylvia-species have ever been recorded in the country (Osborne \& Tigar 1990, Bonde 1993, Hockey et al. 2005), although suitable habitats are available.

\section{Survey of Lesser Kestrel and Amur Falcon}

I have collected data about two common species that were not recorded along the transects, namely Lesser Kestrel and Amur Falcon (Table 3). The number of wintering Lesser Kestrels was estimated at 2500-2800 in eight roosting sites, while that of wintering Amur Falcons at 850-900 in eight roosting sites. Both species prefer farmlands dominated by maize cultivation in the lowlands. Most Lesser Kestrels and Amur Falcons were recorded in the lowlands and in Senque Valley, a few were also observed in the highlands (Table 3). The Amur Kestrels originate from eastern Asia and the Lesser Kestrels mainly from Kazakhstan and southern Russia (Hockey et al. 2005).

\section{Phenology}

Data on phenology (Table 4) indicate that most Palearctic species reach Lesotho quite late. Two species were first observed in August, Little Stint and Common Ringed Plover, and two in September, Ruddy Turnstone and White Stork. The first arrival date of the remaining species was evenly distributed during October, November and December. The species with the latest arrival date was European Golden Oriole. It has also been reported to have arrived in July (Bonde 1993), but this is a doubtful record. The dates given in Table 4 are of course extreme dates that do not show the main arrival periods. The most common Palearctic species, Lesser Kestrel, Amur Falcon and White Stork have their main arrival period in the end of December and depart mainly in February.

\section{A review of the occurrence of Palearctic migrants in Lesotho}

No attempt has been hitherto made to classify Palearctic migrants in Lesotho, and not even the status and abundance of more common migrant 
Table 4. Earliest and latest dates of observations for Palearctic migrants in Lesotho.

Tidigaste och senaste datum för observation av palearktiska flyttfåglar i Lesotho.

\begin{tabular}{|c|c|c|c|}
\hline Species & Earliest date & Latest date & Source \\
\hline Coracias garrulus & 05.12.1999: Roma & - & G. Kopij in AM1999 \\
\hline Ciconia ciconia & 22.09.1984: Roma & - & Kopij 2001 \\
\hline Buteo buteo & 22.10.1999: Roma & 09.03.1998: Roma & G. Kopij \\
\hline Falco naumanni & 26.10.1995: Roma & 09.04.1998: Roma & AM 1999 \\
\hline Falco amurensis & 19.10.2001: Roma & 07.04.1998: Roma & Kopij 2012 \\
\hline Calidiris minuta & 09.08.1971: Roma & - & \\
\hline Actitis hypoleucos & 22.12.2001: Mokhotlong & - & G. Kopij \\
\hline Tringa glareola & - & 23.02.1998: Maseru & G. Kopij \\
\hline Tringa stagnatilis & - & April 1987 & Bonde 1993 \\
\hline Numenius arquata & 16.10.1966: Roma & - & MacLeay in AM1999 \\
\hline Arenaria interpres & 30.09.1973: Maseru & - & D. Halsted \\
\hline Charadrius hiaticula & 26.08.1973: Maseru & - & N.A.L. Lexander (Bonde 1993) \\
\hline Chlidonias hybridus & - & 18.02.1973: Maseru & N.A.L. Lexander \\
\hline Delichon urbica & 29.11.1992: Roma & $\begin{array}{l}\text { 24.03.1996: Roma } \\
\text { 27.04.2000: Matsieng }\end{array}$ & $\begin{array}{l}\text { AM1999 } \\
\text { G. Kopii }\end{array}$ \\
\hline Oriolus oriolus & $\begin{array}{l}\text { 25.12.1996: Roma } \\
\text { 17.07.1964?: Maseru }\end{array}$ & 24.03.1998: Roma & $\begin{array}{l}\text { G. Kopij } \\
\text { Bonde } 1993\end{array}$ \\
\hline Lanius minor & 27.11 .1966 & - & AM1999 \\
\hline Lanius collurio & 13.10.1965: Roma & 06.04.1997: Roma & \\
\hline Muscicapa striata & - & 24.03.2000: Roma & G. Kopij \\
\hline Phylloscopus trochilus & 07.11.1999: Roma & 02.04.2000: Roma & G. Kopij \\
\hline
\end{tabular}

Explanation: AM1999 refers to Ambrose \& Maphisa 1999.

species has been assessed (Bonde 1993). Based on my own quantitative studies and records from literature, the Palearctic species wintering in Lesotho can be divided into four groups:

Common (recorded yearly and numerous $[>100$ birds])

White Stork Ciconia ciconia, Lesser Kestrel Falco naumanni, Amur Falcon Falco amurensis, Common Sandpiper Actitis hypoleucos, Wood Sandpiper Tringa glareola, European (or Common) Black Swift Apus apus, Willow Warbler Phylloscopus trochilus.

Fairly common (recorded yearly, but not numerous $[<100$ birds])

Steppe Buzzard Buteo vulpinus, Common Greenshank Tringa nebularia, European Golden Oriole Oriolus oriolus, Great Reed Warbler Acrocephalus arundinaceus, Spotted Flycatcher Muscicapa striata, House Martin Delichon urbica, Barn Swallow Hirundo rustica, Sand Martin Riparia riparia.

Occasional visitors (1-5 records; 1992-2002)

European Roller Coracias garrulus, European Cuckoo Cuculus canorus, European Nightjar Caprimulgus europaeus, Marsh Sandpiper Tringa stagnatilis, Little Stint Calidris minuta, Curlew Sanpiper Calidris ferrugineus, Common Ringed Plover Charadrius hiaticula, Little Ringed Plover Charadrius dubius, Red-backed Shrike Lanius collurio, Arctic Tern Sterna paradisaea (Allan 1999), White-winged Tern Chlidonias leucoptera, European Sedge Warbler Acrocephalus schoenobaenus.

Vagrants in the past (before 1991):

Corncrake Crex crex: 16.02.1907, Maseru (Winterbottom 1964);

Ruff Philomachus pugnax: 26.01.1973, Roma (Ambrose \& Maphisa 1999);

Curlew Numenius arquata: 16.10.1966, Roma (MacLeay in Ambrose \& Maphisa 1999);

Ruddy Turnstone Arenaria interpres: 30.09.1973, Maseru (D. Halsted in Bonde 1993);

Whiskered Tern Chlidonias hybrida: 18.02.1973, Maseru (N.A.L. Lexander in Bonde 1993);

Lesser Grey Shrike Lanius minor: 27.11.1966, Roma (MacLeay in Ambrose \& Maphisa 1999). 


\section{References}

Alerstam, T. 1990. Bird Migration. Cambridge (UK): Cambridge University Press.

Allan, D.G. 1999. Mega-developments and birds: The waterbirds impacted by the Lesotho Highlands Water Scheme as an example. In: Adams, N.J. \& Slotow, R.H. (eds) Proc. 22 Int. Ornithol. Congr., Durban: 1556-1578. Johannesburg: BirdLife South Africa.

Ambrose, D., Talukdar, S., Pomela, E. M. 2000. Biological diversity in Lesotho. A country study. Maseru: National Environmental Secretariat.

Ambrose, D., Maphisa, D.H. 1999. Guide to the birds of the Roma Campus, National University of Lesotho. Lesotho, National University of Lesotho Publishing House.

Bonde, K. 1993. Birds of Lesotho: a guide to distribution past and present. University of Natal Press, Pietermaritzburg.

Cowling, R.M., Hilton-Taylor, C. 1994. Patterns of plant diversity and endemism in southern Africa: an overview. Sterlizia, 1: 31-52.

Hockey, P.A.R., Dean, W.R.J., Ryan, P.G., Maree, S. (eds.) 2005. Roberts 'Birds of Southern Africa. Cape Town: John Voelcker Bird Book Fund.

Kopij, G. 2000. Birds of Maseru. NUL Journal of Research 8: 104-151.

Kopij, G. 2001a. Birds of Roma Valley, Lesotho. Roma (Lesotho): Department of Biology, National University of Lesotho. 40 pp.

Kopij, G. 2001b. Atlas of birds of Bloemfontein. Roma (Lesotho), National University of Lesotho; 48 pp.

Kopij, G. 2006a. Bird assemblages in natural and urbanized habitats in Morija area, Lesotho. Zeszyty Naukowe Uniwersytetu Przyrodniczego we Wrocławiu, $n r$ 548, Biologia i Hodowla Zwierzat, 54: 69-77.

Kopij, G. 2006b. The structure of assemblages and dietary relationships in birds of South African grasslands. Wrocław, Wydawnictwo Akademii Rolniczej we Wrocławiu; 128 pp.

Kopij, G. 2009. Territoriality in the Willow Warbler Phylloscopus trochilus in its winter quarter in Lesotho. Ornis Svecica 19: 50-54.

Kopij, G. 2012. Changes in numbers of Lesser Kestrels Falco naumanni and Amur Falcons Falco amurensis at a winter roost in Lesotho. Bull. ABC 19(2): 160-165.

Nuttall, R. 2003. The Bloemfontein Swallow Project: 20012003. Afring News 32: 12-15.

Moreau, R.E. 1972. The Palaearctic - African bird migration systems. Academic Press, London.

Osborne, P.E. \& Tigar, B.J. 1990. The status and distribution of birds in Lesotho. Newburry (U.K.): Nature Conservation Bureau.

Salewski, V. \& Jones, P. 2006. Palearctic passerines in Afrotropical environment: a review. J. Orn. 147: 192-201.

Winterbottom, J.M. 1964. Some ms. notes on Basutoland birds by P. Murray. S. Afr. Avif. Ser. 21: 1-10.

\section{Sammanfattning}

Mer än fyra miljarder fåglar av två hundra arter från Palearktis övervintrar i Afrika. Det finns flera gradienter av fågelrikedom. En av dessa är sjunkande antal arter och individer längst i söder. Men ända ner i Kapprovinsen finns paläarktiska övervintrare. En annan gradient går från lågland till högland. Båda gradienterna är aktuella i Lesotho som ligger i södra Afrikas högland och är en enklav i Sydafrikanska republiken. Biotopen är huvudsakligen gräsmarker utan träd och med talrika dalgångar med vattendrag kantade av buskage. Landet är 30000 kvadratkilometer och har två miljoner innevånare som främst lever av jordbruk och boskap. Frånvaron av skogar innebär att skoglevande paläarktiska flyttfåglar saknar lämpliga biotoper även om de kan nå området.

Under åren 1996-2002 studerade jag övervintrande paläarktiska fågelarter och försökte kartlägga deras förekomst, biotopval och fenologi. Det viktigaste arbetet bestod i kvantitativa linjetaxeringar i olika biotoper och höjdlägen på många olika håll i landet. En karta med dalgångarna och de inventerade sträckorna markerade finns i Figur 1. Utöver resultaten från mina egna inventeringar ger jag också en sammanställning av förekomsten av alla påträffade paläarktiska flyttfåglar i Lesotho.

Resultaten från linjetaxeringarna återfinns i Tabell 1 och 2 . Totalt noterades åtta paläarktiska arter längs de $747 \mathrm{~km}$ som transekterna tillsammans omfattade: vit stork, stäppvråk (den östliga långflyttande rasen vulpinus av ormvråk, ofta betraktad som egen art), drillsnäppa, grönbena, dammsnäppa, tornseglare, lövsångare och grå flugsnappare. Storken var den vanligaste arten både i floddalarna och utanför dessa. Normalt finns arten främst i höglandet tillsammans med kor och får, och jag har observerat minst fem hundra vid andra tillfällen än under linjetaxeringarna. Tornseglaren förekommer i Lesotho, men på grund av att den är svår att skilja från den afrikanska Apus barbatus uteslöts den från inventeringen. Lövsångaren var den vanligaste av de två tättingarna och påträffades främst $\mathrm{i}$ videbuskage längs vattendrag och dammar, i låglandet även i akaciabuskar. Lövsångaren lever rätt undangömt och har antagligen underskattats. Det visade sig i mars då den började sjunga och hävda revir inför den förestående flyttningen. Grå flugsnapparen var fåtalig och observerades bara vid bebyggelse. Frånvaron av palärktiska svalor är värd att framhålla eftersom stora övernattningsplatser är kända nära utanför Lesotho.

I Tabell 3 har jag sammanställt förekomsten av rödfalk och amurfalk. Åtta lokaler med minst endera arten redovisas med 2500-2800 rödfalkar och 850-900 amurfalkar. Båda arterna föredrog jordbruksområden som dominerades av majsodlingar.

Här följer en förteckning över alla palearktiska 
flyttfåglar som observerats i Lesotho. Årliga och allmänna (fler än 100 individer per år) arter är vit stork, rödfalk, amurfalk, drillsnäppa, grönbena, tornseglare och lövsångare. Årliga och måttligt vanliga (färre än 100) är stäppvråk, gluttsnäppa, sommargylling, trastsångare, grå flugsnappare, hussvala, ladusvala och backsvala. Fåtaliga (1-5) är blåkråka, gök, nattskärra, dammsnäppa, småsnäppa, spovsnäppa, större strandpipare, mindre strandpipare, törnskata, silvertärna, vitvingad tärna och sävsångare.

Fenologiska data är sammanställda i Tabell 4. Fåglarna anländer relativt sent till Lesotho men första observationerna har stor spridning, från augusti till december. Tabellen anger naturligtvis extremdatum och visar inte huvudperioderna för vistelse i landet. Exempelvis anländer huvuddelen av rödfalkarna, amurfalkarna och vita storkarna i slutet av december och flyttar bort i februari.

Sammanfattningsvis är således den paläarktiska fågelfaunan i Lesotho artfattig och de flesta arter saknas eller är sällsynta. Tiden de vistas i Lesotho är ofta kort, bara ett par månader. Lesotho kan dock vara ett viktigt område för vit stork, rödfalk och amurfalk. 